\title{
Musical forms and spaces
}

The 'acoustic panorama of the Indonesian city' (Colombijn 2007:269) is both distinctive and under-theorized. In Yogyakarta's Sosrowijayan, music and the broader 'soundscape' (Shafer 1977) were integral to the roadside/alleyway division outlined in the previous chapter. These in turn influenced and were influenced by social relations such as those between street guides and becak drivers. Greater Sosrowijayan is hemmed in by three noisy, busy roads, and Sosrowijayan Street itself, which in 2001 was sleepier but nonetheless accommodated waves of motorised transport ranging from motorcycles to trucks and buses. To enter the alleyways off any street, however, within metres the street sounds gave way to a soundscape of kampung activities. Varying with some consistency over the course of each day, sounds included chatter, faint echoes of children playing, murmurs and scuffing shoes of passers-by, devotional sounds from mosques and churches, soap operas on television, melancholy ballads and talkback on radio, guitars and singing, the clinking of cooking utensils and whoosh of gas cookers, trickles of running water, cooing pigeons, and the 'tok tok', 'puk puk puk' and other signals of passing traders (Nakagawa 2000:133-4). The neighbourhood aural environment resulted from a combination of thin walls and open windows, in turn deriving from climatic compatibility and economic scarcity, as well as locally enforced noise regulations such as bans on riding motorised vehicles, and on making undue noise after hours, especially after midnight.

This chapter explores the two main spaces and forms of public music making that regularly took place on the roadsides and alleyways in Sosrowijayan: that of mobile buskers (pengamen) and that at hangouts. Self and cultural expression played a role in both kinds of music making, but they differed in terms of social affiliations, musical genres, and also in their relation to monetary exchange. Moving buskers sought cash directly, while those playing music at 
hangouts did not, although as outlined earlier such locations also served as bases for seeking business. Below I seek to demonstrate how these forms of music making generated and converted various forms of capital, drawing particularly on examples of musical genres that can be plotted broadly along a sub-national/regionalist to globalist axis. The analysis thereby posits links between musical genres and social capital among becak drivers and street guides, and seeks to articulate the roles of these in conflict avoidance in situations such as that at the start of Part One, in which street guides musically colonised a becak drivers' hangout.

MOBILE PENGAMEN

Java has a long history of travelling performers (Body 1982; Cohen 2006), whose forms have ranged from large theatre troupes (Hatley 2008:22-4; Foulcher 2004) to 'street tough' kroncong soloists known variously as buaya (crocodile) and jago (rooster) (Judith Becker 1975). Urban itinerant musicians are socially and financially marginalised yet, paradoxically, are central to the development of many musical forms that powerful politicians subsequently laud as national treasures (Manuel 1988:18). The Indonesian term for busker, pengamen, translates as 'singing beggar'; indeed, like beggars (pengemis), most pengamen in Yogyakarta are poor in economic terms. Unlike beggars however, many elicit some respect, a reflection of their greater cultural capital. In turn, pengamen generate situations that either reinforce or help to transcend boundaries between becak drivers, street guides, and other people on the streets.

In 2001, music making on Yogyakarta's streets and other public spaces projected both court/village and urban/street associations. On the one side, many Javanese street musicians played instruments and forms from, or resembling those of, courtly gamelan orchestras (Lockard 1998:58). As discussed earlier, karawitan, langgam, kroncong and to a degree dangdut all underpin much of what constitutes campursari music. On the other side, many people meant by musik jalanan the generally western-influenced folk/ rock music such as that of national superstar Iwan Fals. While the inner-city anak jalanan term tended to engender sympathy or derision (Solvang 2002), musik jalanan generally carried 'street cred' and pop culture iconography to the point of being a subculture. These court/village and urban/street musics projected regionalist and globalist cultural affiliations respectively, which in turn map broadly onto the becak driver/tourist guide street-worker division. 
My previous encounters with music making around Yogyakarta's streets were a prime reason for choosing this research site. By 2000 however, streetside music making seemed to have waned. I discussed this matter with Mas Gunanto, a local anthropologist who had researched anak jalanan around Malioboro in the 1970s. Gunanto concurred, suggesting that before the 1997 economic crisis pengamen were concentrated in Malioboro, with a different group passing through Sosrowijayan every ten minutes. More recently, he pointed out, most pengamen played on trains, buses and at busy intersections. I too had noticed the explosion of pengamen on public transport and amid the din of traffic intersections. This exacerbated competition for already scarce resources. Many of the new buskers in these locations merely held an instrument and pretended to play it, although a student informed me that this 'dummy playing' was now declining because the public had begun refusing to reward such advances.

While some pengamen in Yogyakarta did not actually play at all, others gave spectacular performances of topical songs, as well as more comforting and familiar traditional ones. On Malioboro Street too there was still a considerable variety of pengamen, including street children who played in the evenings near the Tourist Information Centre (Solvang 2002), and generally older, itinerant musicians in Beringharjo Market. These pengamen trends reflected the sharp rises in urban unemployment and drops in domestic and international tourism at the time. The decreased activity and diversity of musical activity around the inner city was somewhat disheartening; but as described below, this situation at least enabled me to distinguish between the regular and the occasional pengamen around Sosrowijayan.

One regular group consisted of an elderly man and two to three middle-aged women, all dressed in traditional Yogyanese style. They played regionalist karawitan (gamelan music with singing), including the well-known nationalist kroncong melody 'Bengawan Solo' (Solo River) accompanied on a zither (celumpung) and, at times, kendang drum. A husband and wife team recently arrived from East Java, aged 30 and 36 respectively, performed langgam and campursari music. They both sang while he played the zither, and on some evenings he played the same songs as a solo guitarist. Most days the elderly Bu Yani sang langgam and campursari while shaking her tambourine, despite restaurant and eatery staff often admonishing her for repeatedly returning to the same site and customers. Both $\mathrm{Bu}$ Surati and Pak Wasirun were kroncong solo guitarists of long standing in the area whose playing around tables and stalls occasionally gave rise to requests and etiquette-laden bowing. 
All of these pengamen tried their luck at backpacker cafés, the domain of tourist guides, yet their music had more in common with the tastes of becak drivers. As a result, their endeavours to attain economic gain through regionalist cultural projections were rarely successful. Furthermore, foreigners generally favoured the more purist forms of gamelan in their palatial settings, and western pop music, with the relatively hybridized forms of the pengamen falling between the two.

A couple of pengamen acts passing through Sosrowijayan received a more positive response. A young, lower-class woman sang 'Hati yang luka' (A wounded heart; see Yampolsky 1989) in the kroncongstyle thrumbing of her mandolin at the Resto entrance one afternoon. As her friend stood breastfeeding her baby in the background, the performer won the approval of the street-savvy Indonesian women there for the novelty of her rendition. On another occasion, a 40 year old Sumatran man named Girang played his beatenup guitar that had recently fallen from a train, with his baritone voice and delicate plucking style producing soulful cover versions of nostalgic ballads from the early 1970s such as 'Gubahanku' (My composition). In both these cases, the players' unusual renditions of nationalist music bridged regional and national associations into greater social interaction than the other players mentioned above.

In their musical and dress presentations, all of these pengamen manifested what I am calling a regionalist identity, but they varied in terms of the types and levels of capital with which they operated. The karawitan musicians played songs favoured by becak drivers, and they sometimes mingled quietly at food stalls. These interactions, while not based directly on music, seemed to encourage mutual support (including economic support). I noticed on visiting the East Java duo's residence that they owned a colour television and an antique display. When playing in Sosrowijayan however, they usually perched on the dusty ground of roadside café entrances, which suggests that local residents and eatery staff did not pay them much respect. The young woman at Resto briefly interacted with other women there, although the attention she received clearly made her uncomfortable.

Finally, the itinerant pop nostalgia musician mentioned that fellow pengamen often valued the new ideas he brought with him. This exemplifies musical collaboration among buskers at the ingroup occupational level, but also across groups in terms of ethnicity, gender and other identity markers. It also demonstrates that, while pengamen sought economic return, such practices at this level of the economy did not necessarily lead to inter-group tensions and exploitation. Here Girang mentioned congrock (kroncong and 
rock), a new hybrid enjoying increasing popularity at the Simpang Lima Plaza in Semarang that was only beginning to gain currency in Yogyakarta.

In contrast to the above cases, two pengamen groups had a direct influence on social and musical interaction between pengamen, becak drivers and street guides in Sosrowijayan. The first was a fiveman group who sang and played two acoustic guitars, piccolo flute, bottle-top percussion, and dangdut drum. On a typical evening the group would enter from Sosrowijayan's west end and stop in at the relatively high-class Bladok restaurant, and then try the locally patronised warung across the road. They then moved on to the Resto entrance before carrying their gear eastward and into Gang Two, continue through to the T on Gang One, then take either the north or south route, stopping at one or two more places before continuing along Malioboro Street.

The group's Javanese-inflected dangdut with guitar-based kroncong nuances received a mixed reception in Sosrowijayan. One evening at the Resto entrance, their dangdut song was not enthusiastically received. Despite the group's commanding presence, the restaurant staff did not readily dim the stereo, which at this point was playing Sundanese musik degung popular with international visitors. Lacking support from the guides and Resto staff, the group moved on. Their mediocre reception was also due in part to the group's song choice, which had little cultural cachet with staff, guides, and customers.

A different situation arose when the group played at the becak drivers' stand on the evening of Indonesian Independence Day and a couple of weeks after the incident. A few of the Sosro Bahu members sang along with the group. Especially during 'Prahu layar' (Sailboat), a traditional Javanese song by Narto Sabdo currently popular with campursari orchestras, the audience became so enthusiastic that some of the drivers danced on the road. With this combination of national Independence celebrations (not evident anywhere else nearby), rice wine (most becak drivers very rarely drank alcohol), and a dangdut busking group playing familiar regional campursari tunes, the becak drivers were transformed from their normal Sosrowijayan composures into singing and dancing performers. The dangdut combo, for their part, sang with great joy.

In this case, then, the transmutability of dangdut Jawa and campursari helped to facilitate interaction between a pengamen group and becak drivers, who sang along together, exchanged stories and built a sense of solidarity. Regional music and a national theme encouraged a sense of cooperation and trust between the two groups, and did not involve monetary exchange. Passing street guides in the meanwhile neither joined in nor seemed intimidated by the gathering. 
The second, and more influential, pengamen group featuring regularly in Sosrowijayan's public spaces was the Astro Band. Astro Band's extraordinarily large repertoire ranged from campursari, new and old Indonesian pop and regional favourites, to the Beatles and Latin American songs, some of which they experimented with by blending regional, national, and global musical elements. One song request folder they carried contained the Indonesia categories of 'pop hits', 'nostalgia', kroncong, daerah (regional) and kebangsaan (national). Their second folder contained categories such as 'Bowie - England', 'Eagles - Amerika Serikat' and 'Italy'. The Astro Band comprised a core of six men in their early 20s, some of who had come from Surabaya to live in Yogyakarta over the past few years. Their core instruments were double bass, folk guitars, banjo, and two conga drums with a thin chain strapped to them that could be gently tapped and sharply swivelled. Most members sang harmonies and at different times took the lead vocal position. Numerous others also joined in, including fellow street workers such as portrait artists but also holidaymakers and domestic and international students.

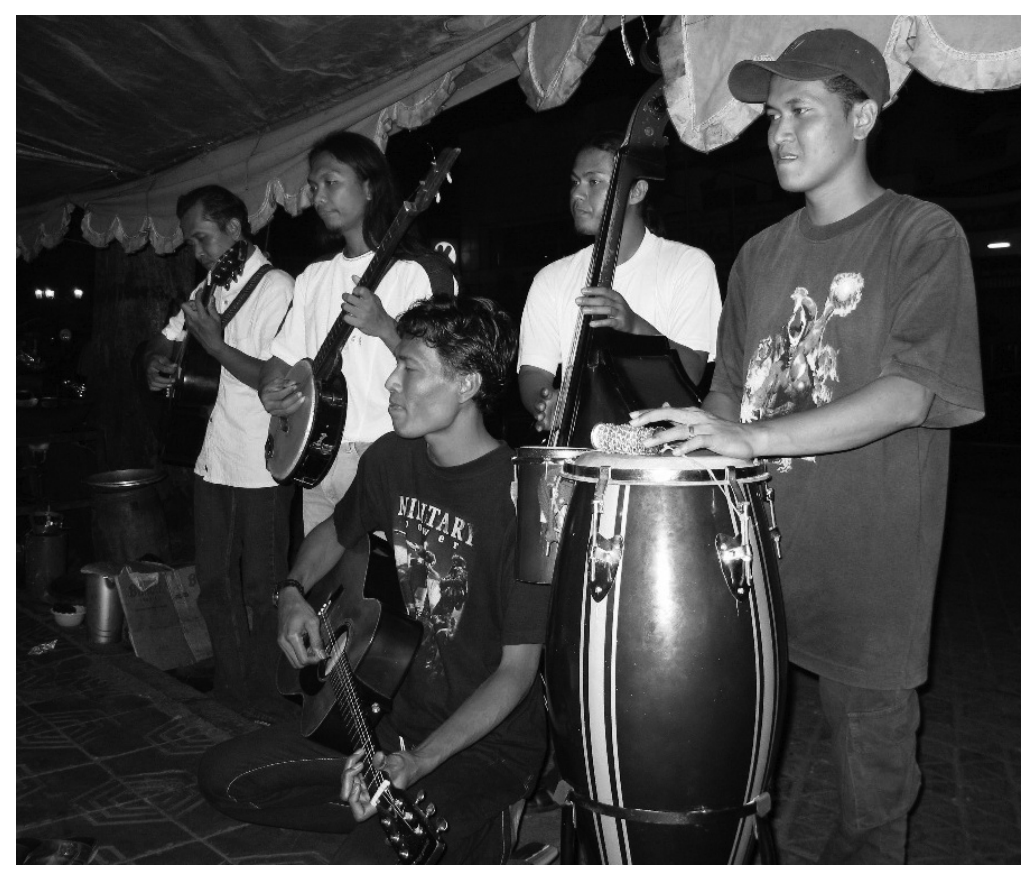

Astro Band playing at Malioboro lesehan, 2001 


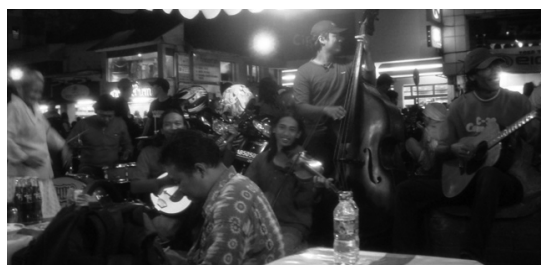

Astro Band playing at Malioboro lesehan, 2009

The Astro Band worked along Malioboro Street and elsewhere every evening, except to attend prayers twice a week. They generally began around seven pm by playing to the lesehan outside Hotel Garuda, where they received anywhere between Rp 500 per song and, on rare occasions such as when a Japanese party hired them on the spot for a whole evening, Rp 300,000 (US\$30). From around midnight until between two and five am, the group usually settled at the Prada eatery on the corner of Sosrowijayan and Malioboro Streets, interspersing their playing with sitting back and sipping tea while chatting and engaging in creative wordplays, known as plesetan (Heryanto 1996:102-3). Unlike the dangdut Jawa group's performance at Sosro Bahu, financial gain clearly remained on Astro Band's agenda. Nonetheless, their combination of music making and hanging about at Prada both built their own experience and knowledge, and at times facilitated interaction between ethnicities, nationalities and, to an extent, class groups. This was especially evident given that many of the participants would otherwise rarely sing together, converse and exchange ideas and information.

While the Astro Band interacted quite freely on the corner of Malioboro Street, their relations with most Sosrowijayan-based workers were more measured. To my knowledge, they never mixed with the Sosro Bahu drivers, although in the early morning hours they sometimes chatted with other becak drivers at another lesehan on Malioboro Street. However, the band sometimes played in the Sosrowijayan alleyways. One evening they broke into song at the entrance to Woodpecker by the $\mathrm{T}$. The music caused quite an impact in this sleepy area, with all band members singing the choruses to their rendition of a popular Latin American song. By the third verse, many of the clientele and staff at the Woodpecker applauded, some placing a few notes (between Rp 500 and 3,000) in the cup that the banjo player circulated while the others continued playing. Although they moved on, their presence served to enliven the area, as was evident when staff at a neighbouring café turned off the talkback radio show and put on a Deep Purple cassette. More generally, 
while well aware of the Sosro Boys' strong territorial claims to the area, Astro members sometimes befriended street guides via such musical exchanges, with guides highly valuing their storehouse of repertoire and playing techniques. As I will further discuss, musical exchanges also helped other 'outsiders' to enter the social world of the guides and, by extension, the Sosro Boys.

Of the pengamen music that featured around Sosrowijayan in 2001, the campursari genre was best able to combine regionalist gamelan-related zithers and langgam scales with nationalist kroncong guitar styles and dangdut rhythms and songs. To some extent, this provided common ground for the tastes of pengamen and becak drivers. By contrast, pengamen who played globalist popular music received some endorsement from street guides and café staff, although such musicians were generally mindful of encroaching onto the guides' territory. In all of these examples, pengamen performed in a context of economic transaction.

\section{STREET-WORKER TONGKRONGAN}

Music at street-worker hangouts (tongkrongan) tended to differ from that of the mobile pengamen in a number of ways. Most often, hangout music making around Sosrowijayan was performed by younger men connected to the street-guide business; and guitars were by far the most common instruments. As mentioned, the kinds and levels of participation in music making in these settings were also not as clearly premised on economic exchange. Features of this music making were prominent at the TransWeb Internet café in Gang One and opposite the Resto restaurant/bar on Sosrowijayan Street, which in turn reflected some of the roadside/alleyway distinctions outlined earlier. To set the context for discussion of these streetguide dominated sites, here I briefly return to the Sosro Bahu stand in the light of tongkrongan music making.

Literally all of the Sosro Bahu drivers I met were intimately familiar with campursari lyrics and song structures. Music at their stand usually served as soothing background to the harsh conditions of the drivers' urban toil, with campursari in particular invoking their fondness for the villages where they typically resided. Usually one or two would quietly sing to a campursari song playing on the radio, either from memory, or with the aid of small lyric booklets. By contrast, one late afternoon around a dozen drivers broke into song, with one using his becak seat as a drum, the only instrument in use. Everybody sang 'Sewu kuto' (A thousand towns), a popular campur- 
sarisong of the time. Most of those present became highly animated, singing with great vigour and stepping rhythmically in and out of joged dancing. The atmosphere quietened down as quickly as it had erupted, and it was only in the villages and at the Sultan's Palace that I was again to see the campursari world of the becak driver come to life.

TRANSWEB

TransWeb Internet café was located by the $\mathrm{T}$ intersection connecting Gang One to a narrow westbound lane. Being close to the Gang One but well away from motorised traffic, TransWeb was part of the aurally sensitive and 'refined' (halus) alleyway environment. The nearby $\mathrm{T}$ was a semi-public zone where neighbouring shop and restaurant staff, their friends and petty tourist goods traders regularly mingled. Particularly in the late afternoon and early evenings, workers would variously survey for potential clients, chat, and recline to rest against the cool walls. Inclusion at the T tongkrongan seemed to rest as much on one's means of livelihood as whether or not one was of Yogya origin (Guinness 1986:128-68).

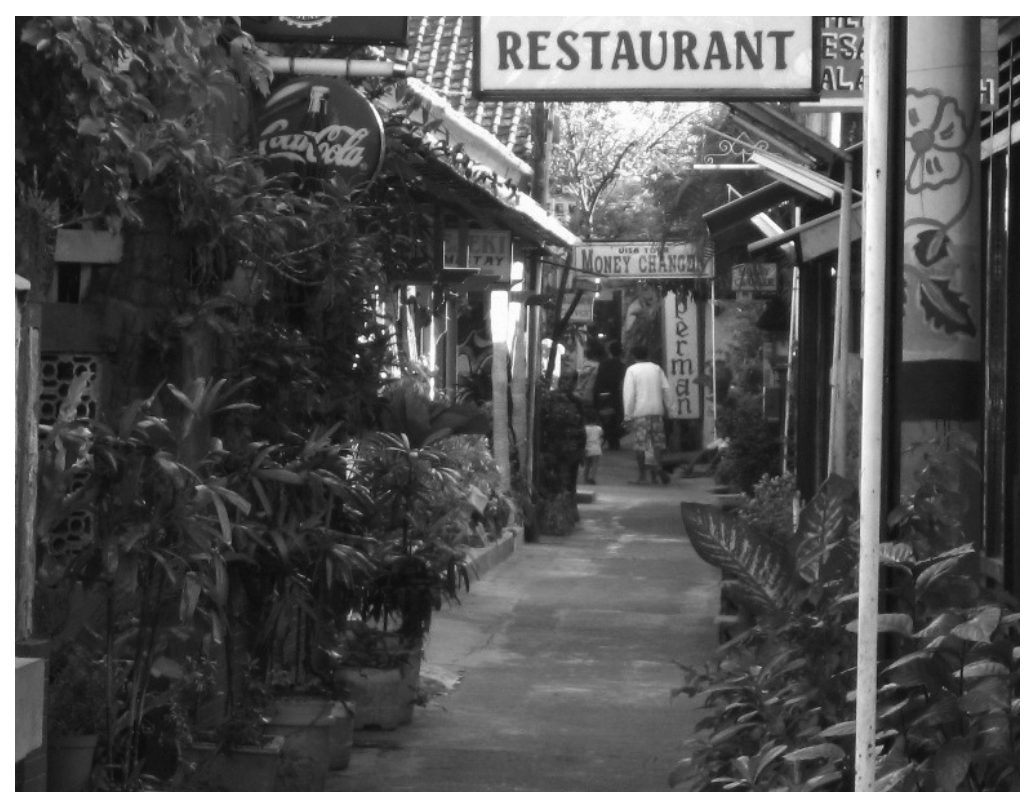

Life is quieter in the kampung 
But becak drivers did not stop in at the $\mathrm{T}$, if for no other reason than that the size of their vehicles prevented it. And the TransWeb staff and their friends socialised close to but actually separate from the T. Guitar playing and singing often emanated from TransWeb, adding to the T's soundscape of background component stereos, hospitality work and general chatter. The internet café's interior had low light and cool but slightly stale air caused by the combination of small fans and constant smoking. There were six small semiopen booths against the three walls, each facing the centre of the room, while more general socialising took place at the service desk, around a low table in the centre of the room, outside on a long park bench between the front window and the gangway, and on the entrance steps themselves.

Pablo, Syari and Chandra ran TransWeb in overlapping shifts. Each had an influence on the people entering their space. Syari was a young woman new to Yogyakarta, and made many friends from outside the city. Pablo and Chandra by contrast were street guides and Sriwisata members with close affiliations with the Sosro Boys. Added to this, Pablo was also a musician and a 'gigolo', meaning a young Indonesian man having intimate relations with a number of older foreign women. Most of the regular visitors to TransWeb were heavily involved in popular music and were at least part-time street guides. There was also a sex worker (or, as will be discussed later, more accurately a perek) known as Doris. Most clientele at TransWeb were young overseas travellers or students. Many of these were newcomers to Yogyakarta, with the convenient location and friendly service as yet preventing their knowledge of TransWeb's relatively high fees. But long-time friends and partners also visited the café regularly.

TransWeb fostered a loose subgroup joining Sosrowijayan insiders and outsiders through popular music and backpacker tourism. The combination of staff, friends and clientele affected social interactions there, as well as the music played. Staff kept the stereo volume below conversation level, and most often played CDs of the Red Hot Chilli Peppers, Moby, Lenny Kravitz, and Eric Clapton. Music making usually involved Pablo's classical guitar, a good quality Japanese-made Yamaha he bought for Rp 200,000 from a tourist in 1998 and kept permanently in the corner of the café. During quiet periods, Pablo would play a blues scale along to an Eric Clapton CD. At other times, Andi would sit on the café veranda and, either on his own or with a young, western woman sitting quietly next to him, sing the Red Hot Chilli Peppers' 'Under the bridge' with a pained expression and draping back his long sweeping hair. On some early evenings, two or 
three people playing guitars would spread across the bench and onto the steps. At these times, the participants often sang $70 \mathrm{~s}$ and 80 s western pop songs such as 'Crazy little thing called love', 'Patience' and 'No woman, no cry', as well as 'Wonderwall' by Britpop group Oasis.

Music making sometimes helped to establish social networks and, in turn, economic gain for street-based workers by linking newcomer guides with Sriwisata members. Andar of Surabaya was a prime example of such capital generation and conversion. Like Ari, a Yogya outsider who, in the incident that opened Part One, negotiated Sosro Boy insider status at the Sosro Bahu becak driver stand, Andar's familiarity with national and international songs and playing styles quickly led to his involvement in street guide social life. His body piercings, mop-top hairstyle, and general pop-star persona complemented his unusually good guitar playing, according him great esteem among his new peers. Problems with his Jakartabased funk band had delayed their album recording project, and so he decided to spend some time in Yogyakarta where, he said, life was easier and more affordable.

Andar's involvement in music making at TransWeb provided an entrée to the status of Sosro Boy, and therefore access to economic opportunity. For example, one quiet afternoon when I visited TransWeb, Andar was playing Pablo's guitar on the steps while Agus and Ari sat on the nearby bench, and Pablo sat with us, except to duck inside to take care of business. Andar returned us to an earlier conversation on guitars, and at their suggestion I brought mine over. Now with two guitars, the opportunity arose for Andar to exchange some of his musical knowledge with the other guides. Their playing and singing became markedly more upbeat and excited as two tall and scantily dressed blonde Scandinavian women entered the $\mathrm{T}$ and stood there for a time. Later, without any western women nearby, they played songs of the Bandung-based band Dewa such as 'Aku di sini untukmu' (I am here for you). Andar showed Agus the accompanying chords, and by the end of the song, they were able to play it together. Andar also played original compositions and improvisations, including tasteful jazz and mood chords, none of which he could name. Later the young men ran through several Doors' songs, with the older female staff inside the Woodpecker restaurant across the way chuckling at their youthfulness.

Music making at TransWeb could incorporate young, urbanoriented newcomers such as Andar. Andar's musical prowess and pop-star style markers, more than his multilingual ability, led to him being included in social occasions such as a Sriwisata birth- 
day party and a large-scale rock performance. Andar thereby utilised his nationalist and globalist musical skills to mix freely in the relatively high economic circles of backpacker cafés. By contrast, music making at TransWeb did not generate any common ground or joint projects with the regular buskers or with the Sosro Bahu becak drivers. Music making at TransWeb, then, generally took place between late afternoon and early evening, often in the context of interactions between Indonesian street guides/gigolo and nonIndonesian women.

The guides' musical interludes at TransWeb did not impose sonically onto the $\mathrm{T}$, and socially too they remained largely separate from their immediate surrounds. The songs the guides played at TransWeb contained many western pop features. Some of the lyrics identified them with the nation, but never with regionalist Javanese lyrics and musical forms. This combination of cultural associations enabled newcomers such as Andar to deploy their globalist musical skills in order to win (or help others to win) the affections of western women, who would then more readily part with some of their money. And as long as the newcomers shared their earnings, this conversion facilitated their acceptance by the local Sosro Boys and enhanced their social acceptance in the kampung.

\section{OPPOSITE RESTO}

The other major music-making hangout involving street guides was what I refer to here as 'Opposite Resto'. Most of those who socialised at TransWeb also frequented Opposite Resto, and the strategic locations of both hangouts served to maximise guides' prospects of meeting foreigners, especially women travellers, although clearly sexual and monetary favours were not their sole interest. But Opposite Resto also differed from TransWeb in that it only came to life at night and, like the Sosro Bahu stand, was situated on Sosrowijayan Street.

People gathered at moveable benches by a dimly lit cigarette stall directly opposite Resto cafe/bar, and on the ground around five metres to the east, while by day the locale was no more than a closed stall and a patch of dirt on the roadside. ${ }^{1}$ Being on a road

1 By 2009 a 'Circle K' convenience store had been installed here. The extended steps at the storefront, known as pantai (beach), became Sosrowijayan's most crowded night-time gathering place. 


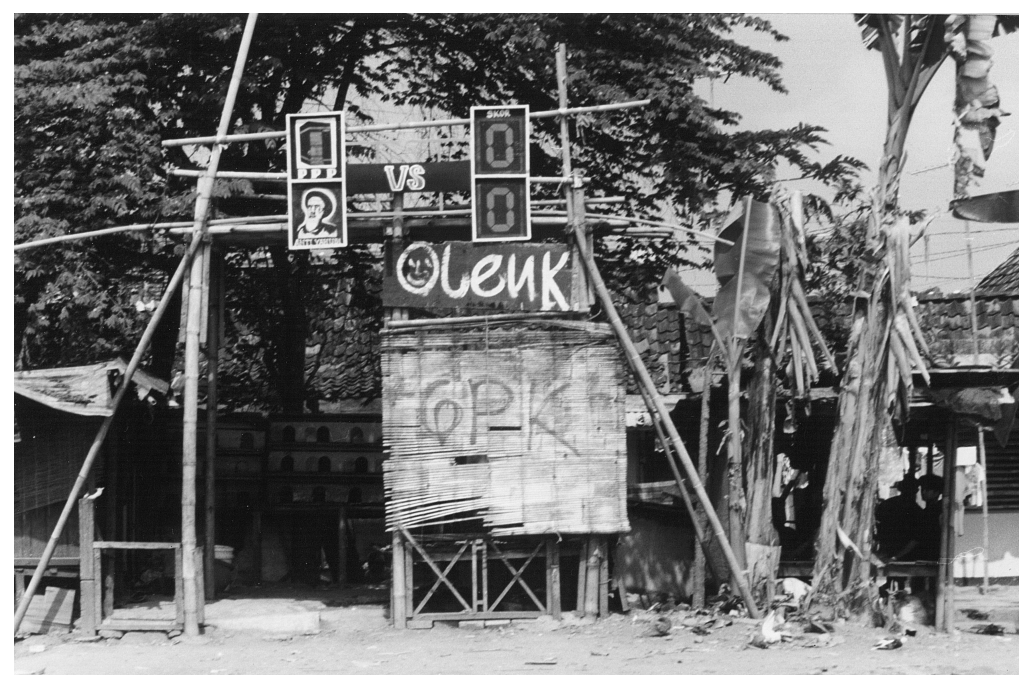

A 'base camp' some 20 metres to the east of the Opposite Resto tongkrongan, where members of the sometimes-militant Gerakan

Pemuda Ka'bah (GPK, Ka'bah Youth Movement) gathered

and distant from residents, and therefore not subject to kampung regulations, Opposite Resto had few noise restrictions in terms of both music making and the motorcycles, trucks, and buses that encroached into participants' physical and aural space. Again in contrast to TransWeb, alcohol consumption was popular, participant numbers could reach 30 or more, and music making here sometimes extended into acoustic jam sessions with whole groups singing out choruses.

People at most tongkrongan, in particular the angkringan tea stalls, seemed to welcome or at most be indifferent to the arrival of an outsider (Murray 1991:59). In contrast, Opposite Resto lacked a clear spatial boundary, and its primary function, unlike that of drinking tea or eating a snack, often shifted. There was a greater tendency towards volatility there, in part due to its strategic position allowing the guides to catch business prospects entering, leaving or merely passing Resto. Any guardedness displayed toward outsiders may seem accountable by the illicit activities taking place there, if not for the fact that prominent signage for, and sale of, homebrew alcohol were on display for a time. Music making was a regular feature, but so too accounts of recent violence circulated quite openly, perhaps in turn influenced by its location near a political 'base camp' where militant street campaigners gathered. 
One evening I joined a small group at Opposite Resto. Six of us sat on the ground exchanging songs while passing round three guitars and two large water bottles filled with 'Sunrise' (beer, vodka, and Kratindaeng energy drink). As we sat and drank, playing music took precedence over talking. Edi swayed back and forth as others played the blues. Ari suggested and then sang the U2 song 'With or without you' with passionate conviction; the entire song is a repetition of four basic chords, so we accompanied him with ease. We also played and sang national-language jalanan songs by Iwan Fals, Sawung Jabo and others, ranging from lighter relationship themes, such as 'Kumenanti seorang kekasih' (Waiting for a lover), to the anti-New Order classics 'Bento' and 'Bongkar' (Tear it down). Newcomer Andar in each case added colourful embellishments on guitar, again enhancing his cultural capital. On this occasion however, just as Andar and I had begun to exchange Javanese langgam scales, a former guide named Han suddenly stood and, turning to the sky, screamed 'Fuck off!' while throwing his motorbike helmet crashing across the road. Unlike the younger, more optimistic Sosro Boys, Han's bitter cross-cultural relationship experiences both alienated him from, and made him aggressively protective of, Javanese language and music. Significantly however, Han never behaved aggressively in the kampung environment of TransWeb.

A similar incident occurred on another evening inside Resto itself. Han and Studs were slouching back on dining chairs and quietly playing older protest songs such as Pink Floyd's 'Another brick in the wall' and the Doors' 'People are strange', and then Swami's 'Bongkar'. A young American man approached and asked if they knew any Didi Kempoet or Sheila on 7. His familiarity with these Javanese musicians, campursari and pop stars respectively, at first generated laughter and apparent acceptance among the guides. Then Han suddenly shouted 'Yha Sheila, fuck you!' at which point the young American quietly withdrew. Han and a few others sometimes showed signs of excessive shabu shabu methamphetamine consumption, including glazed eyes and a trembling, sweat-drenched body. His exclamations were by no means typical of the street guides, although I did hear of an episode at Opposite Resto one night when a French student was beaten up after making a joke in Javanese.

Drug use, oppositional music, and occasional abrasiveness characterised the Opposite Resto tongkrongan. But it was also more likely to be a place for spontaneous humour and creative expression. One evening as I approached the stall there to buy a cigarette, the atmosphere was tense and unpredictable. Of the 20 or so people there, most were drinking, and four men and a woman sitting by the stall were engaged in creative plesetan. One of the men, looking 
worn down by long bouts of deep thinking, sat with his face turned to the moon and, rare at Sosrowijayan tongkrongan, sang a lyrically and musically spontaneous song, in this case about the futility of seeking to pin down the meaning of life. The Opposite Resto hangout on this evening was characterised by a kind of blunt directness and honesty; participants were neither keen to please nor testy with those around them.

The final Opposite Resto example involved Han, a rough diamond known as Stan, and one of my main respondents, Tyas. As we sat to a drink, two young gigolo/guides also joined in from busking in Prawirotaman, Yogyakarta's other, quieter and more middle-level backpacker area. With songs played on two guitars and drinks flowing, Stan and others urged the few westerners passing by to join the 'full moon party'. A German with dreadlocks and a quiet Austrian couple joined the gathering, and a few other street guides stopped by for a drink and chat before wandering on. Musical renditions included lyrical alterations directed at tourists. Han bellowed out the Eagles' 'Hotel California' with the line 'this could be heaven or this could be Holland [hell]'; while another, perhaps in sympathy with Han, sang Bob Marley's 'I shot the tourist [sheriff]'.

Later however, they played songs by Indonesian musicians. Tyas accompanied on Ebiet G. Ade's 'Nyanyian rindu' (Song of longing) in a calypso style, with the guides singing the choruses in parody of Ebiet's intensely self-exploratory vocal style. At another point, he played a Spanish-style modal lead break to the evergreen protest song 'Bongkar', to which Studs accompanied with shouts of 'Ole!' I found it quite striking that Tyas' musical proficiency on this occasion helped to steer the increasingly intoxicated participants away from potential antagonism and into outbursts of musical expression. His nationalist and globalist musical skills enabled him, firstly, to express sympathy with Han, and then to ensure that Han did not indulge in any tendency towards physical aggression.

A number of similarities and contrasts characterised music making at Sosrowijayan's main tongkrongan. ${ }^{2}$ Sosro Bahu members possessed a vast knowledge of campursari music, or what might be called (sub-national) regionalist cultural capital. However, the environment was not compatible for making music: despite lyrics harking to a simpler village life, it is paradoxical that playing regionalist campursari in its full glory required gamelan instru-

2 Jeremy Wallach's discussion (2008:140-62) of street-based workers and music at a tongkrongan in South Jakarta illustrates the generally greater level of inter-ethnic interaction that features on Jakarta's streets. 
ments, keyboards and a supply of electricity. Therefore, campursari at the stand soothed and to an extent bonded the becak drivers, but they did not convert any in-group solidarity that this generated into economic gain or extended social influence.

While the main function of campursari for Sosro Bahu drivers was to invoke other places and times within the region, TransWeb regulars sometimes used music making with national and international inflections to enhance their social status. Street guides and their friends in my experience never played the regionalist genres enjoyed by the becak drivers and regularly performed by pengamen. At Opposite Resto, many participants consumed alcohol, and the music involved angst and political protest to a greater extent than was the case at TransWeb. Older guides, some of whom risked marginalisation while others were regarded as success stories, influenced this. The example of Tyas' influence on the volatile Han demonstrates how music can promote peaceful social interaction in this context.

Becak drivers shared with the majority of itinerant pengamen passing through the kampung a taste for regionalist campursari music. While this provided some common ground among them, street guides by contrast mobilised their ability for globalist music making to enter the economic realm of backpackers. More specifically, both TransWeb and Opposite Resto had in common the guitar playing of male street guides; in both cases music played a central role in drawing in relatively wealthy foreigners, from whom the street guides could exchange their cultural for economic capital. ${ }^{3}$ The next chapter locates these informal musical interactions in the context of the formation, agendas and activities of two musical groups based in Sosrowijayan, both of whom carried versions of these genres and cultural associations into the realm of organized public performance.

3 Interestingly, by 2010 several mid-range hotels had been established along the south side of Sosrowijayan Street. These were in the main patronised by middle-class Indonesians from outside of Yogyakarta, including families and business and government groups. This provided new avenues for business among becak drivers, but less so for street guides. 